\title{
Climate driven changes in subtidal kelp forest communities in NW Spain
}

\author{
Sofie E. Voerman ${ }^{\mathrm{a}, \mathrm{b}, *}$, Eva Llera $^{\mathrm{c}}$, José M. Rico ${ }^{\mathrm{c}, \mathrm{a}}$ \\ ${ }^{a}$ Departamento de Biología de Organismos y Sistemas, Unidad de Ecología, Universidad de Oviedo, C/ Catedrático Rodrigo Uría s/n, 33071 Oviedo, Spain \\ ${ }^{\mathrm{b}}$ Plant Functional Biology and Climate Change Cluster, School of the Environment, University of Technology Sydney, NSW 2007, Australia \\ ${ }^{c}$ Centro de Experimentación Pesquera, Dirección General de Pesca, Escuela de Formación Profesional Náutico-Pesquera, \\ 2a planta Avenida Príncipe de Asturias s/n, 33212 Gijón, Spain
}

\section{A R T I C L E I N F O}

\section{Article history:}

Received 11 March 2013

Received in revised form

17 June 2013

Accepted 22 June 2013

\section{Keywords:}

Algae

Sea surface temperature

Climate change

Laminaria ochroleuca

Habitat loss

Fisheries

Community composition

Bottom up

Bay of Biscay

Invasive

\begin{abstract}
A B S T R A C T
Reconstructions suggest a massive decline of nearly 1400 ha of kelp forest in North Western Spain in 2007. In line with global rising temperatures, we hypothesized that Sea Surface Temperature (SST) surpassed a lethal threshold for kelp. We examined whether changes in SST correlated to the proposed decline in kelp forest. All investigated SST characteristics suggested to affect kelp abundance increased significantly during the past thirty years, reaching extreme values during the last decade. In addition over the past two decades, the landscape formerly dominated by both cold and warm temperate canopy forming and understory species changed to one dominated by warm temperate understory species, resulting in a loss of vertical community structure. Fisheries landing data of kelp associated species was used to support the suggested change in kelp abundance. Subsequent recovery of the kelp appears to be occurring in deeper waters.
\end{abstract}

(C) 2013 Elsevier Ltd. All rights reserved.

\section{Introduction}

Kelp often form dense beds on hard substrate in the shallow subtidal and intertidal zones of temperate and polar waters. These forests form the foundation for many ecological and physical processes, providing numerous ecosystem services (Lünning, 1990; Steneck et al., 2002). Kelp acts as both substratum for many sessile animals and algae and as habitat for mobile organisms living in and feeding directly on the kelp or their associated species (Duggins, 1980; Christie et al., 2009). A decline in habitat-forming subtidal kelp unsurprisingly results in major changes in near shore community composition (Schiel et al., 2004; Wernberg et al., 2012).

Elevated temperatures negatively affect survivorship, growth, reproduction, recruitment and resilience to disturbances of kelps from temperate coasts (Vandenhoek, 1982; Izquierdo et al., 2002;

\footnotetext{
* Corresponding author. Plant Functional Biology and Climate Change Cluster, School of the Environment, University of Technology Sydney, NSW 2007, Australia.

E-mail address: Sofie.Voerman@uts.edu.au (S.E. Voerman).
}

Wernberg et al., 2010, 2011a,b). Thus temperature thresholds are a major determinant of broad-scale kelp distribution, with their tolerance to summer maxima being critical for controlling their biogeographical boundaries (Breeman, 1988; Lünning, 1990; Schils and Wilson, 2006). Warming of the planet has accelerated in recent years and is predicted to continue over the next century (IPCC, 2001; Burrows et al., 2011). Subtidal kelp may be especially vulnerable to changes in sea surface temperature (SST) due to their cold-water affinities (Lünning, 1990). Therefore, changes in subtidal algae distribution are expected with increased SST (Muller et al., 2009).

The central coast of North West (NW) Spain straddles an important geographic boundary between colder and warmer waters. In contrast to the often observed transitions in north-south direction, a longitudinal thermal gradient exists along the coast of Asturias in summer (Garcia et al., 2011). This makes Asturias a key location for the study of kelp in relation to changing SST. Several kelp species that dominate subtidal communities along the Atlantic coast of Europe show a continuous distribution from the Arctic to Brittany. Further south they are only present in areas of intense 
upwelling, where cool water is transported to the ocean surface. This leads to a transition between cold and warm temperate floras south along the coast of Portugal (Tuya et al., 2012) and north in Asturias (Lünning, 1990; Gutiérrez morán, 1994). In Asturias, upwelling events are frequent in summer driven by north-easterly winds. The presence of Cape Penas (Fig. 1) strengthens winddriven upwelling to the west, further accentuating differences in SST (Valencia et al., 2004). Consequently kelp species in Asturias occur close to their upper temperature limit, restricted by warm summer SST to the east. In 2007 anecdotal evidence indicated a massive decline of the main kelp species Laminaria ochroleuca Bachelot de la Pylaie. This was supported by qualitative assessment of the region by independent professional divers with an extensive knowledge of the study area.

Often no prior information on species distribution or abundance is available when unexpected ecological changes occur. In these circumstances employing fisheries as natural experiments offers a tremendous opportunity for testing the effects of perturbations in natural systems (Jensen et al., 2012). The use of commercial fisheries has been widely employed as an indicator for ecosystem change (e.g. habitat modification and changes in primary productivity) (Libralato et al., 2004; Okada et al., 2005), and climate change (Qui et al., 2010). In particular, studies demonstrate a positive relationship between kelp and decapod abundances (Johns and Mann, 1987; Daly and Konar, 2010; Irigoyen et al., 2011). In this study we make use of this relationship by employing decapod landing data as an indication of changes in kelp abundance, as no quantitative data on kelp abundance was present directly prior to the decline.

The aim of this study was to evaluate whether changes in SST characteristics were responsible for the proposed decline of the main kelp species $L$. ochroleuca. In line with global rising temperatures, we hypothesized that summer SST reached a lethal threshold causing changes in the kelp forest community.

Firstly, starting from the 1980s, we analyzed the trends in SST characteristics suggested to affect kelp abundance using satellite data. Additionally we evaluated changes in kelp forest community over the past 20 years in NW Spain. We estimated area loss of kelp forest by the indicated former distribution of kelp by the independent divers. Thereby we compared semi-quantitative abundance data of kelp communities after the decline, with a semiquantitative reference study from the early 1990s. Changes in kelp associated decapods landing were analyzed to support the suggested kelp decline. Finally we provide an assessment of the potential recovery of lost kelp forest, important for considering long term effects of climatic perturbations of marine ecosystems. This study provides an assessment of potential mechanisms behind kelp loss, a worldwide phenomenon of great concern, and the use of fisheries as a valuable tool for indicating changes in habitat availability when no other data is available at the necessary spatial or temporal scale.

\section{Materials and methods}

\subsection{Study area}

This study was conducted in Asturias, along the mid northern coast of Spain at the southern end of the Bay of Biscay (Northeastern Atlantic), where a transition in summer SST and between cold and warm temperate floras can be found around Cape Penas (Anadon and Niell, 1980; Lünning, 1990) (Fig. 1).

\subsection{SST variables}

SST data was obtained from Advanced Very High Resolution Radiometer sensors from the NOAA-12 to NOAA-18 satellites. SST time series from the NOAA Optimum interpolation $0.25^{\circ}$ daily seasurface temperature analysis (OISST version 2 ) were used. The series is based on the methods described in Reynolds et al. (2007), and it is produced and maintained by C. Liu and R.W. Reynolds at NCDC (www.ncdc.noaa.gov/oa/climate/research/sst/oi-daily.php). Individual daily time series at 29 pixel locations between January 1982 and December 2011 between $43.4^{\circ}$ and $44.0^{\circ} \mathrm{N}$ and -8.0 and $-4.0^{\circ} \mathrm{W}$ were used to describe patterns in the coastal area of Asturias, and were analyzed as described below.

Mean summer and winter SST of the period 1982-1992 were calculated. Summer was defined as the three warmest (July, August, September) and winter as the three coldest months (January, February, March). The period of 1982-1992 was suitable as the reference period as it represents the thermal habitat of the historic vegetation of the 1990s referred to in this study. Differences between mean SST of winter and summer months over the period 2000-2012 in relation to the reference period are calculated for all satellite data points $(N=29)$ and visualized by interpolation by a thin-plate smoothing spline procedure with SAGA GIS (version 2.0.8, 2011) (Boehner and Antonic, 2009).

Data from one satellite data point, situated in the middle of the study area $\left(43,625^{\circ} \mathrm{N}, 6625^{\circ} \mathrm{W}\right)$, was used to calculate the yearly number of days of (i) SST $>20^{\circ} \mathrm{C}$, (ii) maximum consecutive days of SST $>20^{\circ} \mathrm{C}$, (iii) mean summer and (iv) yearly maximum SST. Trends were analyzed using linear regression analyses.

\subsection{Macroalgae data}

Since no data on the distribution of kelp was available prior to its decline in 2007, an estimate was made by soliciting the experience of 3 independent professional divers with experience in the collection of algae and with extensive knowledge of the study area. Each of the divers highlighted the former distribution of L. ochroleuca on maps of the study area in detail. Their indications overlapped extremely well. The indicated distributions were then combined to form one, schematic estimation (by Alvarez Raboso,

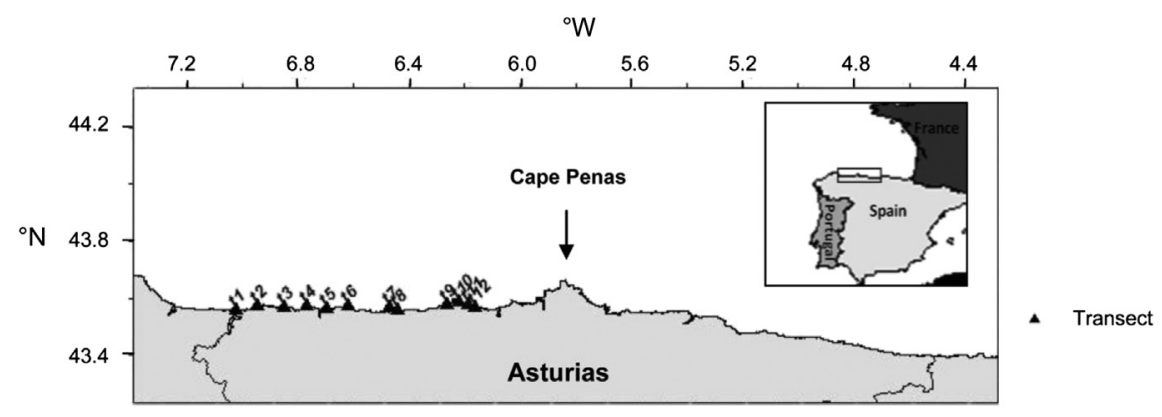

Fig. 1. Map of study area with location of sampling sites. 
2009). This was mapped in Quantum GIS (version 1.7.4) and analyzed for area cover.

In order to follow changes to the kelp forest community from 2009, twelve transects west of Cape Penas were positioned along $150 \mathrm{~km}$ of coastline (Fig. 1 ). The transects were surveyed annually (2009-2011) during the months of May-August to detect the abundance of macroalgal taxa in the subtidal at 0-25 $\mathrm{m}$ depth below Lower Low Water level (LLW). Transects were distributed along the coast at places which, according to the just described methods, would have been formerly covered with L. ochroleuca forest in order to investigate any potential recovery.

At each station algal abundance, depth and distance from the starting point were measured and the algae abundance in the form of percentage surface cover was estimated visually (in situ) in plots of $2 \times 2 \mathrm{~m}^{2}$. Photos were taken of each plot, and checked for surface cover estimates. Algae were identified to species level, or assigned to higher taxonomic categories where species identification was not possible.

For the investigation of changes in kelp forest communities over past decades, the survey of 2009 was compared with three $100 \mathrm{~m}$ transects surveyed perpendicular to the coast by McNeill in 1992 (McNeill, unpubl. report). In the study by McNeill all macroalgae were identified, and abundances were recorded using a $2 \times 2 \mathrm{~m}^{2}$ quadrat at $2 \mathrm{~m}$ intervals. McNeills transects were less than $1 \mathrm{~km}$ from transects t4, t8 and t9 (Fig. 1).

McNeills main conclusions were that kelp forests (Saccorhiza polyschides and L. ochroleuca) were [translated quote] "dominant as canopy species at 0-2 m depth, while understory species were also very similar in the three transects. Between 2 and $6 \mathrm{~m}$ depth up to 30 individuals of $S$. polyschides per $\mathrm{m}^{2}$ and a mixed assemblage of L. ochroleuca and Laminaria hyperborea were found. Between 6 and $10 \mathrm{~m}$ depth $S$. polyschides density dropped to 6 plants per $\mathrm{m}^{2}$ and an increase in L. ochroleuca and Cystoseira bacatta was observed". Overall, kelp species were the dominant feature in the three transects. The semi-quantitative surveys of 1992 and 2009 were compared for the $0-10 \mathrm{~m}$ depth interval, as in 1992 only the shallow subtidal was sampled.

To visualize changes in kelp forest community composition, characteristic algae of depth zones $0-2,2-6$ and 6-10 m depth were described according to the methods of McNeill (1992, unpubl. report), for comparison. The algae of 1992 were identified as dominant when present in at least $20 \%$ of the descriptions (three descriptions per transect). As McNeill (1992, unpubl. report) did not describe a threshold in abundance for dominant or non-dominant species, the algae of the survey in 2009 were indicated dominant when present with a minimal surface cover of $20 \%$ in at least $20 \%$ of the stations. In total 63 stations divided over 12 transects were sampled in the 0-10 m depth interval in 2009 (Fig. 1).

The categorization in vertical zonation (canopy forming or understory algae) was adopted from McNeill (1992, unpubl. report). To determine changes in community composition in terms of species thermal affinities, the geographic distribution of each taxon, assumed to reflect their thermal affinities, was explored. Thermal affinities of the key species were adjusted from their known distribution in Lünning (1990), and indicated as either northern, cold temperate, or southern, warm temperate species. Taxa that were identified as northern, cold temperate, typically had a distribution from the coast of Norway southwards and with a most southern distribution north or in central Portugal. Species with a southern, warm temperate, distribution were present further south, sometimes until Cape Verde (West Africa). Where no information was given in Lünning (1990), the distribution as determined by Gorostiaga et al. (2004), Barbara et al. (2005) and Araujo et al. (2009) was adopted. Taxa were indicated as cosmopolitan whenever no clear restriction in distribution was found. L. ochroleuca is a Lusitanian species, with a distribution from Morocco up to the northern Hebrides (United Kingdom), and its distribution in the NW Iberian peninsula is probably associated with the Galician upwelling system.

Potential recovery of $L$. ochroleuca was further examined by investigating changes in abundance measured as absolute frequency, i.e. the number of stations in which L. ochroleuca is present. A separation was suggested by Gutiérrez morán (1994) between the shallow subtidal $(0-10 \mathrm{~m})$ and the deeper subtidal $(12+\mathrm{m})$, as changes occur in species composition around this depth in Asturias.

In order to obtain a balanced design 2 plots per depth level per transect were selected at random. This excluded the use of transect \#1 and transect \#2. Separate analyses were carried out for the different life stages (juvenile and adult). Changes in abundance of life stages (as absolute frequency) between the years 2009-2011 were investigated for each depth level separately with a Pearson's Chi square test. This analysis was also used to compare the difference in abundance (as absolute frequency) of each life stage between depth levels in each year (2009-2011). Chi square tests were conducted in Past, version 2.15 (Hammer and Harper, 2001).

\subsection{Decapod landing}

All target species were caught with traps, placed just under LLW. Five fishing vessels were selected based on whether they had been fishing for the selected associated species. Target species were crab species Necora puber Lineus and Maja squinado Herbst and slipper lobster Scyllarus arctus Lineus, selected based on their close association with kelp as their food resource or habitat (Freire and GonzálezGurriarán, 1998; Norman and Jones, 1992; Bernárdez et al., 2000). Fluctuations in abundance of the selected kelp-associated species should be interpreted with care as a direct connection between the selected species and kelp forest abundance has not yet been investigated for communities as present in NW Spain. A direct link between the investigated species and increased SST was not expected, as the natural range of these species extends to the warm Mediterranean Sea (Ingle, 1980; Flores and Paula, 2001; Sekiguchi et al., 2007). Landing data was supplied by the Fisheries Institute of Asturias (Dirección General de Pesca, Asturias). No data is available on the exact fishing effort. However by the continuity of the vessel size, gear used, number of fishermen, expertise of the fishermen and area fished in, we assumed that effort was constant through the years, and landing depended on the availability of the target species.

\section{Results}

\subsection{SST trends}

Mean (and standard deviation; SD) winter and summer SST were $12.7^{\circ} \mathrm{C}(\mathrm{SD}=0.089, N=29)$ and $19.4{ }^{\circ} \mathrm{C}(\mathrm{SD}=0.575, N=29)$ respectively for the period 1982-1992. In summer SST was highest east of Cape Penas, with a thermal divergence of nearly $2{ }^{\circ} \mathrm{C}$ between the eastern and western part of Asturias.

We observed an increase in mean SST in both summer and winter between 1982-1992 and 2002-2012, over the full extent of the coastal zone of Asturias. This increase was nearly four-times stronger in summer than in winter, with a mean increase of $0.52{ }^{\circ} \mathrm{C}(\mathrm{SD} 0.039, N=29)$ and $0.14{ }^{\circ} \mathrm{C}(\mathrm{SD} 0.028, N=29)$ respectively (Fig. 2). Mean summer SSTs west of Cape Penas of the past decade are now comparable with temperatures that were once common only east of the Cape in the 1990s.

The yearly number of days of (i) SST $>20^{\circ} \mathrm{C}$, (ii) maximum consecutive days of SST $>20^{\circ} \mathrm{C}$, (iii) mean summer and (iv) yearly maximum SST increased significantly from 1982 to 2012 (Fig. 3; Table 1). The yearly number of days of SST $>20^{\circ} \mathrm{C}$ was highest in 2006 (Fig. 3a). The number of consecutive days of SST $>20{ }^{\circ} \mathrm{C}$ 

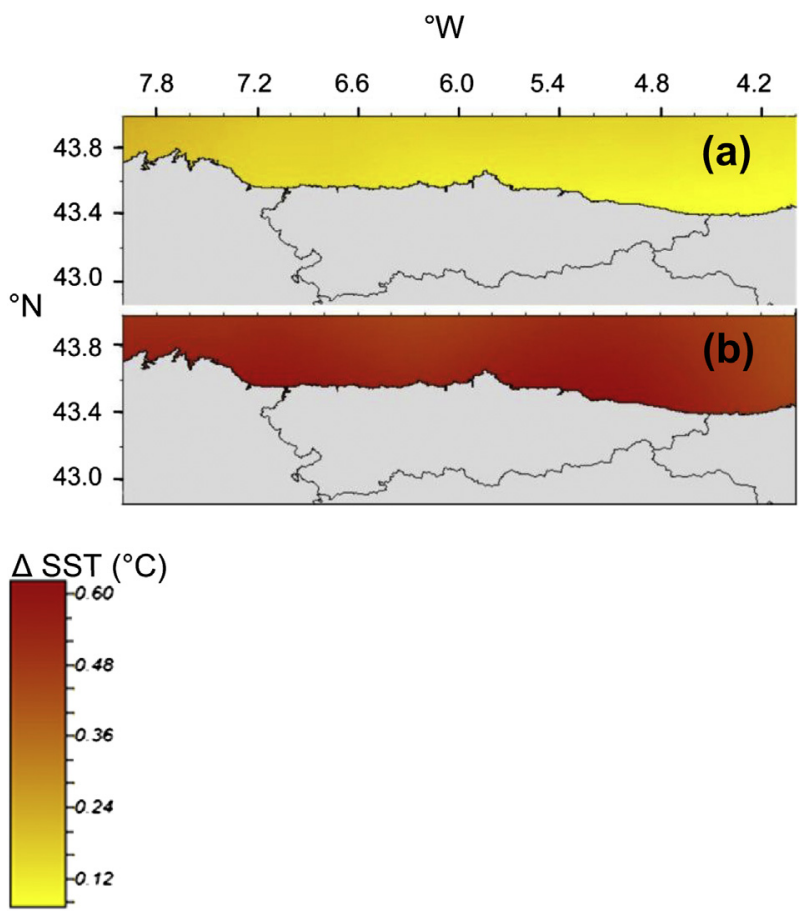

Fig. 2. SST change $\left({ }^{\circ} \mathrm{C}\right.$ ) between mean winter (a) or summer (b) SST of the periods 1982-1992 and 2002-2012.

showed peaks in 1999, 2003 and 2006 (Fig. 3b). The highest summer mean SST was found in 2006 with $20.9{ }^{\circ} \mathrm{C}$ (Fig. 3c) and maximum SST measured peaked in 2003 and 2006 with SSTs of $23.0^{\circ}$ and $22.8^{\circ} \mathrm{C}$ respectively (Fig. $3 \mathrm{~d}$ ).

\subsection{Changes in kelp forest community}

West of Cape Penas, 71 patches of Laminaria forests were described before 2007, forming dense stands of around 60 plants per $\mathrm{m}^{2}$ in the low intertidal or the shallow subtidal (Alvarez Raboso, 2009). The patches had a mean surface area of more than 19ha and in total they covered more than 1400 ha. Disappearance occurred all along the Asturian coastline, over a stretch of more than $150 \mathrm{~km}$.

We identified a reduction in number of canopy forming species, with 7 canopy forming algae present in the 1990s described by McNeill (1992, unpubl. report) and only 4 canopy forming algae in the past decade (2007-2010) (Table 2). Moreover, only juveniles of L. ochroleuca were present, and hence did not contribute to the canopy.

In addition we indicated an increase in abundance of several understory species, all with warm water affinities, of which Cladophora spp. can be classified as opportunistic (Juanes et al., 2008). An increase in abundance of the alien species Asparagopsis armata was also noted in the investigated area (DAISIE, 2008).

\subsection{Changes in decapod abundance}

All three species showed similar patterns in landings. Landing increased from the year 2002-2003 or 2004 for all vessels and species (Fig. 4). A decrease in landing is observed from 2005 onwards for all species and most vessels, to levels less than $20 \%$ of the landings observed in 2003 and 2004. M. squinado and S. arctus (Fig. 4b, c) landings decreased moderately or fluctuated initially, following a steep decrease in 2007, 2008. During the years 2010 and 2011 we observed an increase in yearly landing of all decapod species.
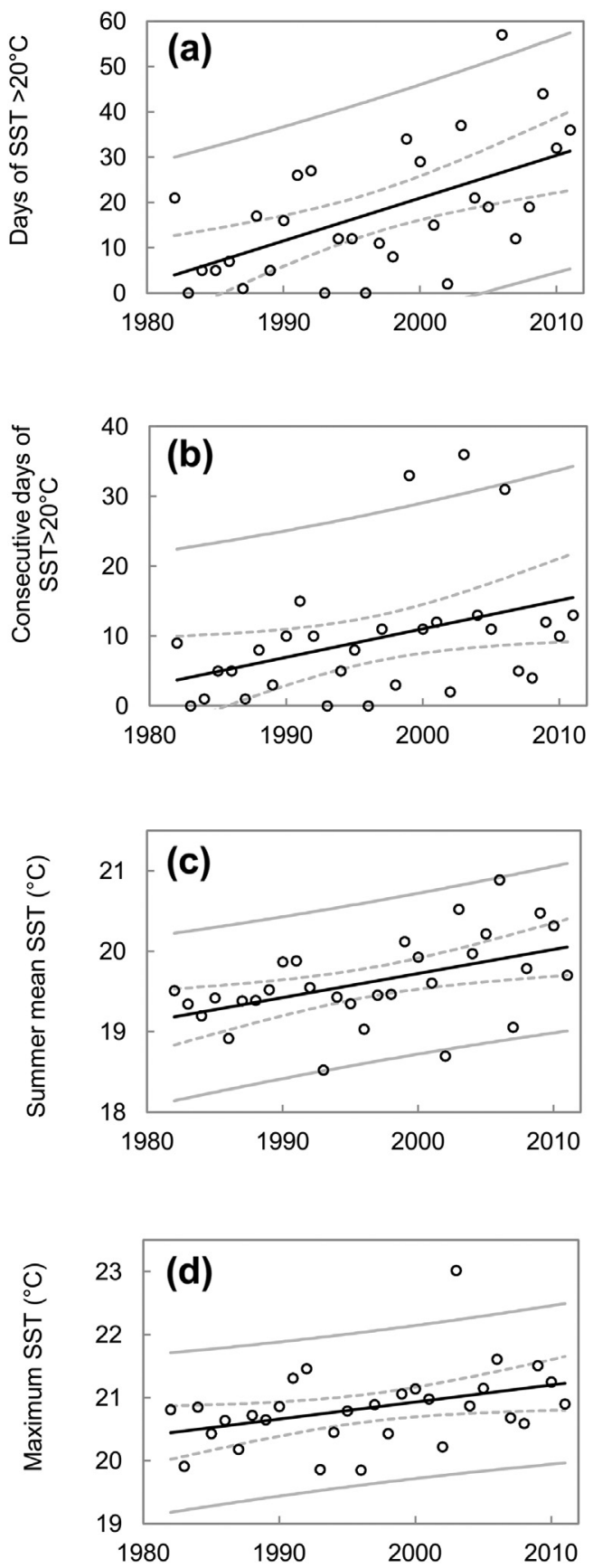

Fig. 3. Temporal SST trends: (a) yearly number of days of SST $>20{ }^{\circ} \mathrm{C}$, (b) yearly maximum number of consecutive days of SST $>20^{\circ} \mathrm{C}$, (c) yearly mean summer SST and (d) yearly maximum SST from satellite data $\left(43,625^{\circ} \mathrm{N}, 6625^{\circ} \mathrm{W}\right)$ over the period 1982-2012. Solid black line: model; dotted gray lines: confidence interval (Mean 95\%); solid gray lines: confidence interval (Observations 95\%). Notice the different scales.

Table 1

Linear regression analyses representing the relationships between time and the number of days with SST $>20^{\circ} \mathrm{C}$, mean summer SST, maximum consecutive days of SST $>20^{\circ} \mathrm{C}$ and maximum SST over the period $1982-2012$.

\begin{tabular}{llllll}
\hline Variable & $N$ & Slope (*year) & $R^{2}$ & $F$ & $p$ \\
\hline Days $>20{ }^{\circ} \mathrm{C}$ & 30 & 0.950 & 0.333 & 14.002 & $\mathbf{0 . 0 0 1}$ \\
Consecutive days $>20^{\circ} \mathrm{C}$ & 30 & 0.408 & 0.152 & 5021 & $\mathbf{0 . 0 3 3}$ \\
Summer mean SST & 30 & 0.030 & 0.239 & 8.771 & $\mathbf{0 . 0 0 6}$ \\
Maximum SST & 30 & 0.027 & 0.147 & 4.833 & $\mathbf{0 . 0 3 6}$ \\
\hline
\end{tabular}

Bold numbers indicate significant values $(p<0.05)$. 
Table 2

Main macroalgal taxa west of Cape Penas in the late early 1990s century and the past decade in the shallow subtidal, classified by vertical zonation. Biogeographic distribution is indicated as northern, cold temperate (no); southern, warm temperate (so); cosmopolitan (co) or alien (al). Information on pigment content is indicated as ochrophyta (ochr); chloryphyta (chl); rhodoficea (rhodo). Species indicated in bold where identified as dominant. (+) Indicates an increase of the taxa abundance, $(-)$ indicates a decrease of the taxa abundance.

\begin{tabular}{|c|c|}
\hline 1992 & 2009 \\
\hline \multicolumn{2}{|l|}{ Canopy } \\
\hline Cystoseira baccata (so) (ochr) & Cystoseira baccata (so) (ochr) \\
\hline (-) Desmarestia ligulata (so) (ochr) & Desmarestia ligulata (so) (ochr) \\
\hline (-) Desmarestia aculeata (no) (ochr) & Saccorhiza polyschides (so) (ochr) \\
\hline (-) Halidrys siliquosa (no) (ochr) & *Laminaria ochroleuca is present, \\
\hline (-) Laminaria ochroleuca (so) (ochr) & but only in juvenile form, not \\
\hline (-) Laminaria hyperborea (no) (ochr) & forming canopy \\
\hline \multicolumn{2}{|l|}{ Saccorhiza poyschides (so) (ochr) } \\
\hline \multicolumn{2}{|l|}{ Understory } \\
\hline (-) Calliblepharis ciliata (so) (rhodo) & $(+)$ Asparagopsis armata $(\mathrm{al})$ \\
\hline (-) Corallina spp. (so) (rhodo) & (rhodo) \\
\hline (-) Chondrus crispus (no) (rhodo) & Corallina spp. (so) (rhodo) \\
\hline (-) Dictyopteris polypodioides & (+) Codium spp. (so) (chloro) \\
\hline (so) (ochro) & $(+)$ Cladophora spp. (co) (chloro) \\
\hline (-) Dilsea carnosa (no) (rhodo) & (+) Dictyota dichotoma (so) (ochro) \\
\hline Gelidium corneum (so) (rhodo) & (+) Gelidium corneum (so) (rhodo) \\
\hline (-) Polyides rotundus (no) (rhodo) & (+) Stypocaulon scoparium (so) (ochro) \\
\hline (-) Pterosiphonia complanata & (+) Jania squamata (so) (rhodo) \\
\hline (so) (rhodo) & Plocamium cartilagineum (so) (rhodo) \\
\hline $\begin{array}{l}\text { Plocamium cartilagineum (so) } \\
\text { (rhodo) }\end{array}$ & $\begin{array}{l}\text { (+) Sphaerococcus coronopifolius } \\
\text { (so) (rhodo) }\end{array}$ \\
\hline Ulva spp. (co) (chloro) & Ulva spp. (co) (chloro) \\
\hline
\end{tabular}

\subsection{Potential recovery}

There was a significant association between the year and the abundance of adults in the deeper subtidal, with adults being more likely to be present later (Table 3, Fig. 5). A posteriori pair-wise tests showed significant differences between the years 2009 and 2011 $\left(\mathrm{df}=1, \chi^{2}\right.$ value $\left.=10, p<0.005\right)$ in abundance of adults. However, no forest ( $>50 \%$ cover) of $L$. ochroleuca was present by 2011.

In 2009 and 2011 there was a significant difference in the abundance of juveniles between the shallow and deeper subtidal zones, with a higher abundance in the deeper subtidal zone (Table 4). No significant differences between depth levels were found for adult abundances.

\section{Discussion}

This study indicates changes in kelp forest abundance and its substitution by a warm temperate understory flora have been driven by changes in summer SST. Importantly, SST trends are not continuous through time nor space (Lima and Wethey, 2012). Our results emphasize the importance of seasonal analyses, as by solely looking at trends in yearly average SST important factors contributing to ecosystem change might be underestimated or even undiscovered. Both the calculations from the summer SST changes between the past decade and the reference period and the general linear model indicated a significant increase while the winter SST trend appeared to be minor and was not significant. This supports the study by Gomez-Gesteira et al. (2008) who found a mean summer increment of SST in the Cantabrian coast for the period 1985-2005 of $0.37^{\circ} \mathrm{C}$ per decade and no significant trend in winter.

Our results indicate that all northern, cold temperate species may have changed their distribution limits. This is supported by other studies conducted along the northern coast of Spain, east of our study area (Fernandez, 2011; Diez et al., 2012). Also Tuya et al. (2012) express their concerns on kelp retreat in northerly direction along the coast of Portugal. This evidence indicates a widespread
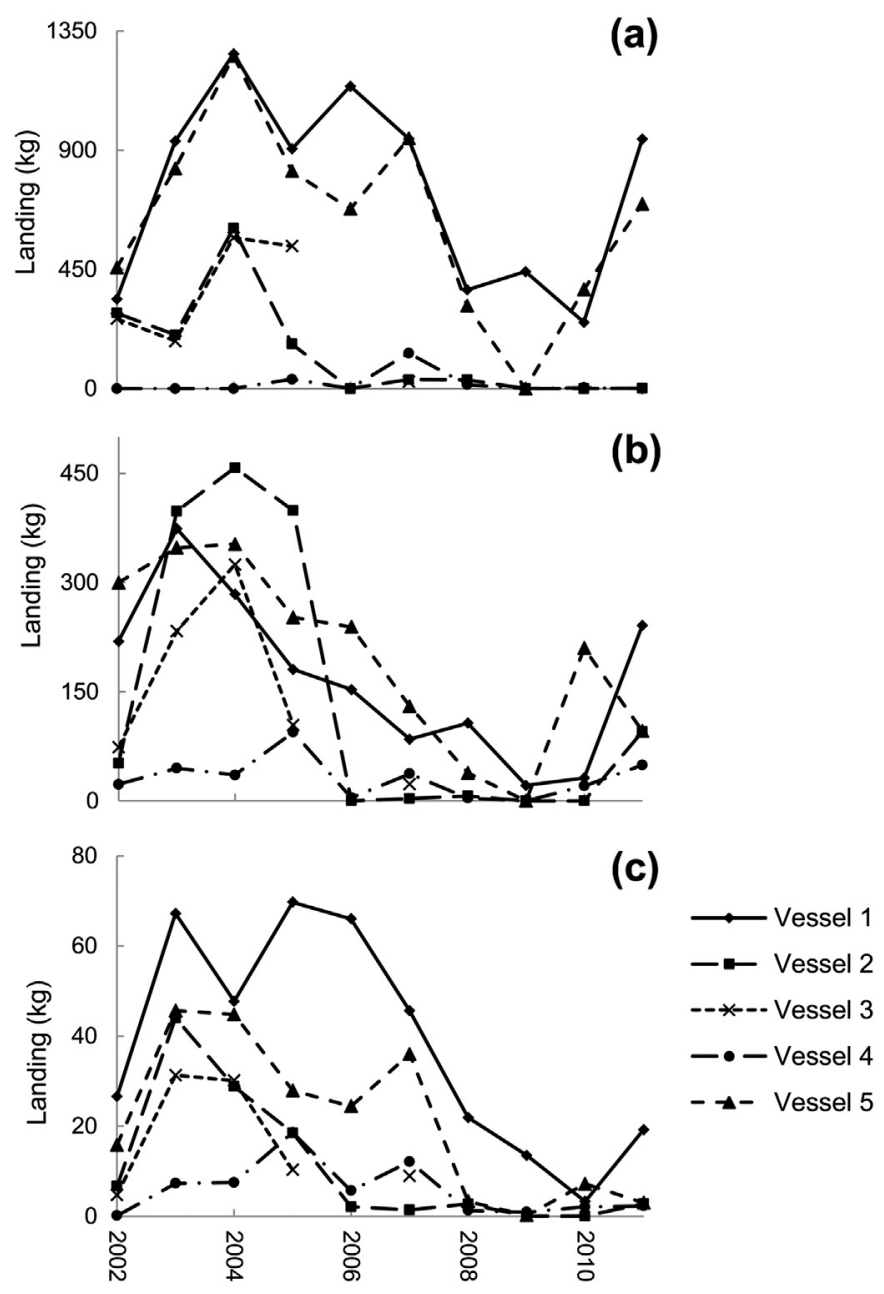

Fig. 4. Yearly landing (kg) per vessel of (a) N. puber, (b) M. Squinado and (c) S. arctus. Notice the different scales.

contraction in the range of cold temperate kelp species in this region of upwelling. Similar retreats of cold water algae corresponding to warmer summer SST have been described globally (e.g. in France, Cosson (1999); southern Norway, Moy and Christie (2012); Japan, Tanaka et al. (2012); Australia, Wernberg et al. (2009)).

In this study we also showed that several warm temperate, understory species increased their abundance. SST warming may have enhanced the growth and/or reproduction and/or competitive ability of these warm-temperate species. Alternatively, a reduction in survival of cold temperate species might also have allowed for their expansion into newly available space (Vandenhoek, 1982). This study indicates that the shift in temperature regime in our study area is reflected in changes in the algal community composition, that nowadays resemble those found in the eastern part of Asturias during the early 1990s (McNeill, 1992, unpubl. report). This

Table 3

Results $\chi^{2}$ test for differences in abundance (as absolute frequency) of L. ochroleuca life stage between years (2009-2011) per depth level. $N=20$.

\begin{tabular}{lllcl}
\hline Depth level & Live stage & df & $\chi^{2}$ value & $p$ \\
\hline Shallow (0-10) & Juvenile & 2 & 4.450 & 0.108 \\
& Adult & 2 & 4.205 & 0.122 \\
Deep (12+) & Juvenile & 2 & 3.733 & 0.155 \\
& Adult & 2 & 10.909 & $\mathbf{0 . 0 0 4}$ \\
\hline
\end{tabular}

Bold numbers indicate significant values $(p<0.05)$. 


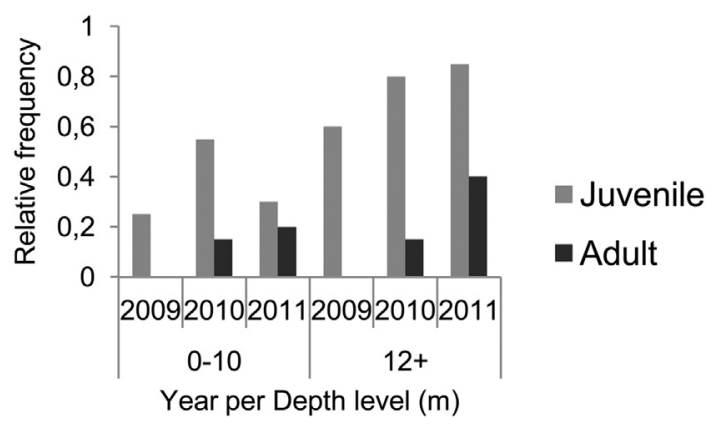

Fig. 5. Relative frequency (the number of stations in which $L$. ochroleuca is present divided by the total number of station in that class) of different life stages of L. ochroleuca in time per depth level. Gray bars: relative frequency of juveniles. Black bars: relative frequency of adults. $N=20$.

suggests that SST increase can shift whole biota within only 15 years. These results are consistent with the unexpected decline of some warm temperate algae. Most of these algae showed a biogeographic gradient in the 1990s with increased abundance to the west, such as Corallina spp., P. Complanata and Calliblepharis sciliata. At a smaller scale species interactions are more important in shaping species distribution than temperature (Arrontes, 1993). Interspecific competition with other macroalgae might have excluded the expansion of these species to the east in the early 1990s, and negatively affected the abundance of the previously mentioned algae during the past decade. Lima et al. (2007) also detected an unexpected retreat of warm water species along the coast of Portugal and discuss biotic interactions as a potential explanation. Our study highlights the importance of considering population dynamics in predicting future changes relating to environmental changes.

Also an increase in abundance of the exotic alga Asparagopsis armata was suggested in this study. This is supported by Diez et al. (2012), who found a spread of $A$. armata along the Western Basque coast, east of Asturias, over the past two decades, particularly in areas where canopy forming algae were missing. Disturbance of native seaweed canopy is an important contributing factor to the establishment of invasive algae (Valentine et al., 2007), and the loss of kelp may have facilitated the spread of invasive macrophytes.

Increased SST can affect species abundance without necessarily changing the spatial distribution of the species itself (Wernberg et al., 2012). Locally, it can affect species abundance by affecting available suitable habitat (Simpson et al., 2011). We showed that landing of the three kelp associated decapods declined soon after the extreme warm summer of 2003 and 2006, consistent with a common underlying driver of change. This most likely indicates a decrease in suitable habitat (kelp) during that period, as already proposed by the descriptions of the professional divers. Climate change is affecting marine communities in numerous ways; however it has been argued that its indirect effect by the loss of habitat forming organisms is of even greater concern (Schiel et al., 2004). In

\section{Table 4}

Results of $\chi^{2}$ test for differences in abundances (as absolute frequency) of L. ochroleuca between shallow $(0-10 \mathrm{~m})$ and deep $(12+\mathrm{m})$ subtidal per life stage. In 2009 and 2010 tests for differences in adult abundance between depth levels are not applicable by equal abundances. $N=20$.

\begin{tabular}{lcclll}
\hline Year & Juvenile & & & \multicolumn{2}{l}{ Adult } \\
\cline { 2 - 3 } \cline { 2 - 3 } & $\chi^{2}$ value & $p$ & & $\chi^{2}$ value & $p$ \\
\hline 2009 & $\mathbf{5 . 0 1 3}$ & $\mathbf{0 . 0 2 5}$ & & \\
2010 & 2.849 & 0.091 & & 0.168 \\
2011 & $\mathbf{1 2 . 3 7 9}$ & $\mathbf{0 . 0 0 0}$ & 1.905 & 0 \\
\hline
\end{tabular}

Bold numbers indicate significant values ( $1 \mathrm{df})(p<0.05)$. this study we also showed an increase in decapod landing from 2010. This possibly resulted from a recovery in kelp forest, directly improving food and/or habitat availability.

\subsection{Potential causes of the kelp decline}

Although our conclusions must be interpreted with caution given an absence of a time series prior to the decline of $L$. ochroleuca forest - the magnitude of the indicated changes in the abundance of most macroalgae and SST characteristics can be considered outside the range of natural variability (Walker, 1956). Also the uniform direction of change in abundance of cold temperate and warm temperate taxa is unlikely to be caused by stochastic variation alone. In addition changes in the abundance of kelp forest are supported by changes in associated decapod abundance. Thus it is reasonable to assume that the changes in kelp forest abundance and composition are a result of the changes in SST over past decades.

Changes in several SST characteristics potentially negatively affected kelp abundance. Firstly, changes in periods longer than 30 consecutive days of SST $>20{ }^{\circ} \mathrm{C}$ are considered as a stressor for S. polyschides (Fernandez, 2011). This might also be applicable for L. ochroleuca as both species show comparable temperature tolerances (Lünning, 1990). A second factor investigated was chronic exposure to thresholds conducive to growth reduction, which is suggested to result in a decline in abundance of the affected algae (Wernberg et al., 2010). Temperatures higher than the critical temperature of $20^{\circ} \mathrm{C}$ negatively affect the growth and productivity of L. ochroleuca (Table 5). A third investigated potential driver behind kelp loss is an increased mean summer SST, often suggested to shape lower latitudinal distribution limits of macroalgae (Breeman, 1988, 1990; Muller et al., 2009; Smale and Wernberg, 2013). The Lusitanic members of the Laminariales, S. polyschides and L. ochroleuca, have their southern distribution limits at the $20^{\circ} \mathrm{C}$ mean SST isotherm in summer, at the boundary of southern Morocco and Western Sahara (Lünning, 1990). Finally we considered maximum SST, known to affect kelp abundance. The kelp species S. polyschides and L. ochroleuca have an upper lethal limit of the sporophyte phase at temperatures of $24^{\circ} \mathrm{C}$ (Lünning, 1990) and $23^{\circ} \mathrm{C}$ (Table 5) respectively.

Our results showed that all SST characteristics investigated increased over the past 30 years, reaching extreme high values during the past decade. Lethal limits for $S$. polyschides and $L$. ochroleuca in maximum consecutive days of SST $>20^{\circ} \mathrm{C}$, summer mean SST and maximum SST were reached in the east of Cape Penas, but not in the west (unpublished in situ SST data, provided as Supplement 1). Increased mean SST is likely the cause of the reduction of $S$. polyschides and $L$. ochroleuca forests to small patches and isolated individuals east of Cape Penas (Fernandez, 2011). In the west, the increase of number of warm days potentially accounts for the sudden kelp decline. The other three SST characteristics investigated might also have contributed to the decline in the west, despite no thresholds have been surpassed, because experimentally determined threshold temperatures might vary under natural

Table 5

Optimum and critical temperatures for different phases and processes of the life history of L. ochroleuca.

\begin{tabular}{lll}
\hline Life history process & $\begin{array}{l}\text { Optimum } \\
\text { temperature }\end{array}$ & $\begin{array}{l}\text { Lethal temperature } \\
\text { limit }\end{array}$ \\
\hline Growth gametophyte & $15-18{ }^{\circ} \mathrm{C}^{\mathrm{b}}$ & $21^{\circ} \mathrm{C}^{\mathrm{a}}$ \\
Reproduction gametophyte & $11^{\circ} \mathrm{C}^{\mathrm{a}} / 12-18{ }^{\circ} \mathrm{C}^{\mathrm{b}}$ & \\
Sporophyte growth & $15-20^{\circ} \mathrm{C}^{\mathrm{a}}$ & $22-23^{\circ} \mathrm{C}^{\mathrm{a}}$ \\
Reproduction sporophyte & $15-16^{\circ} \mathrm{C}^{\mathrm{a}}$ & \\
\hline a Tom Dieck (1992). & & \\
b Izquierdo et al. (2002). & &
\end{tabular}


conditions as multiple factors play a role in the resilience of the kelp species (Bartsch et al., 2008). Moreover, the interactions of these stressors potentially led to a critical situation west of Cape Penas. The other kelp species with known prior distribution in Asturias, L. hyperborea, has a maximum survival SST of $21^{\circ} \mathrm{C}$ (Lünning, 1990). Temperatures exceeding this level have been measured all along the Asturian coast during the past decade (Supplement 1), which is a likely explanation of the disappearance of this kelp species.

\subsection{Consequences of the kelp decline}

The disappearance of $L$. ochroleuca and other canopy forming species with a co-occurring increased importance of understory taxa reduced the vertical structure of the system (Fig. 6). This negatively influenced both habitat availability and diversity (Goodsell and Connell, 2002; Arroyo et al., 2004) and correspondingly threatens species richness and abundance, including commercially important species as also indicated in our study (Airoldi et al., 2008). Hence a loss in kelp abundance and diversity can have social, economic and ecological impacts. The seriousness of kelp forest loss is arguably comparable to that of coral bleaching or deforestation. In the shallow subtidal zone, the effects of the loss of $L$. ochroleuca are possibly mediated by the presence of S. polyschides. A loss in diversity of kelp associated fauna can be reduced when neighboring habitats were proximate (Goodsell and Connell, 2002). However, a decline of S. polyschides has already been observed east of Cape Penas (Fernandez, 2011; Diez et al.,
2012). Thereby it should be noted that $S$. polyschides is an annual kelp species, in contrast to the perennial L. ochroleuca, which may influence faunal composition (Christie et al., 2009).

Our study showed a recovery of $L$. ochroleuca after the decline, as previously predicted by increased decapod landing. These observations suggest the good relationship between kelp abundance and decapod landing data. The observed recolonization also agrees with the known fast recovery potential of kelp (Barradas et al., 2011). The recovery of adult plants that was observed in the deeper subtidal zone might be explained by the observed increased abundance of juvenile plants at this depth level. Competition between L. ochroleuca and S. polyschides normally results in a gradient with S. polyschides dominant in the shallower parts and L. ochroleuca at depth (Lünning, 1990; Gutiérrez morán, 1994). In Asturias there also occurs an increased abundance of $S$. polyschides in the shallow subtidal (Voerman and Rico, unpublished data). Established populations of potential competitors can reduce the probability of recruits becoming established, potentially resulting in the increased presence of juveniles at depth (Izquierdo et al., 2002; Reed et al., 2004). Temperatures are also mediated with depth, and therefore survival of microscopic stages or juveniles of $L$. ochroleuca might be enhanced (Izquierdo et al., 2002; Smale and Wernberg, 2009; Pereira et al., 2011), resulting in the observed recovery of L. ochroleuca at depth. Despite the recovery that we observed, 4 years after the decline there is yet no kelp forest present, despite kelp being known for their fast recovery and L. ochroleuca in particular being one of the more thermophile kelp species.
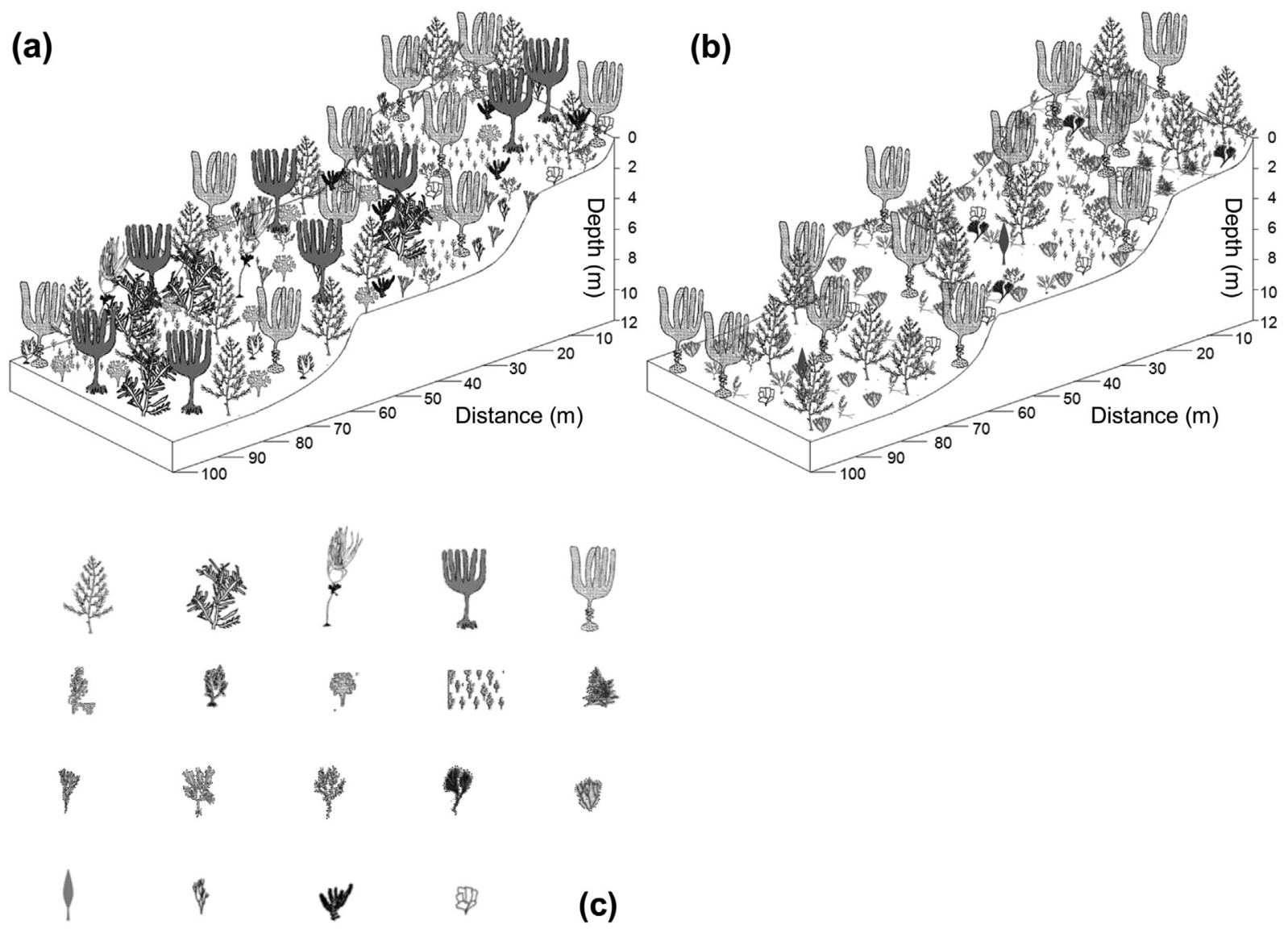

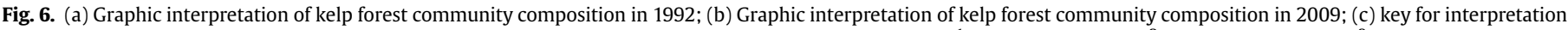

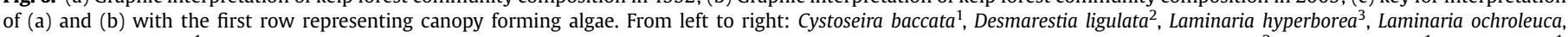

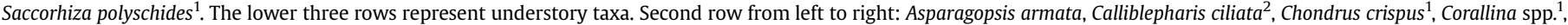

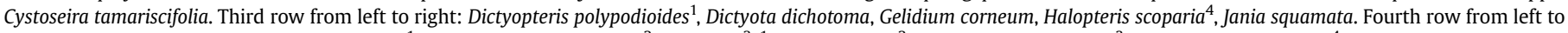
right: juvenile L. ochroleuca, Polyides rotundus ${ }^{1}$, Pterosiphonia complanata ${ }^{2}$, Ulva spp. ${ }^{2}{ }^{1}$ McNeill, $1992,{ }^{2}$ Gutiérrez morán, $1994,{ }^{3}$ www.ukmarinesac.org, ${ }^{4}$ www.biobib.de. 


\section{Acknowledgements}

This work was supported by the Centro de Experimentación Pesquera of the Direccion General de Pesca del Principado de Asturias. We are grateful to Jesús A. Raboso and Jorge Chachero for support during the diving. The authors thank Paul Gribben and the anonymous reviewers for their valuable comments. SEV is thankful to the EMBC program providing an Erasmus Mundus scholarship.

\section{Appendix A. Supplementary data}

Supplementary data related to this article can be found at http:// dx.doi.org/10.1016/j.marenvres.2013.06.006.

\section{References}

Airoldi, L., Balata, D., Beck, M.W., 2008. The Gray Zone: relationships between habitat loss and marine diversity and their applications in conservation. Journal of Experimental Marine Biology and Ecology 366, 8-15.

Alvarez Raboso, J., 2009. Prospección de los bosques de laminarias en la costa occidental del principado de Asturias, p. 78.

Anadon, R., Niell, F.X., 1980. Distribución longitudinal de macrófitos en la costa asturiana ( $\mathrm{N}$ de España). Investigación Pesquera 45, 143-156.

Araujo, R., Barbara, I., Tibaldo, M., Berecibar, E., Tapia, P.D., Pereira, R., Santos, R., Pinto, I.S., 2009. Checklist of benthic marine algae and cyanobacteria of northern Portugal. Botanica Marina 52, 24-46.

Arrontes, J., 1993. Nature of the distributional boundary of Fucus-Serratus on the North Shore of Spain. Marine Ecology - Progress Series 93, 183-193.

Arroyo, N.L., Maldonado, M., Perez-Portela, R., Benito, J., 2004. Distribution patterns of meiofauna associated with a sublittoral Laminaria bed in the Cantabrian Sea (north-eastern Atlantic). Marine Biology 144, 231-242.

Barbara, I., Cremades, J., Calvo, S., Lopewz-Rodriguez, M.C., Dosil, J., 2005. Checklist of benthic marine and brackish Galician algae (NW Spain). Anales del Jardín Botánico de Madrid 62, 69-100.

Barradas, A., Alberto, F., Engelen, A.H., Serrao, E.A., 2011. Fast sporophyte replacement after removal suggests banks of latent microscopic stages of Laminaria ochroleuca (Phaeophyceae) in tide pools in northern Portugal. Cahiers De Biologie Marine 52, 435-439.

Bartsch, I., Wiencke, C., Bischof, K., Buchholz, C.M., Buck, B.H., Eggert, A., Feuerpfeil, P., Hanelt, D., Jacobsen, S., Karez, R., Karsten, U., Molis, M., Roleda, M.Y., Schubert, H., Schumann, R., Valentin, K., Weinberger, F., Wiese, J., 2008. The genus Laminaria sensu lato: recent insights and developments. European Journal of Phycology 43, 1-86.

Bernárdez, C., Freire, J., Gonzalez-Gurriaran, E., 2000. Feeding of the spider crab Maja squinado in rocky subtidal areas of the Ria de Arousa (north-west Spain). Journal of the Marine Biological Association of the United Kingdom 80, 95-102.

Boehner, J., Antonic, O., 2009. Land surface parameters specific to topo-climatology. In: Hengl, T., Reuter, H.I. (Eds.), Geomorphometry: Concepts, Software, Applications. Elsevier.

Breeman, A.M., 1988. Relative importance of temperature and other factors in determining geographic boundaries of seaweeds - experimental and phenological evidence. Helgolander Meeresuntersuchungen 42, 199-241.

Breeman, A.M., 1990. Expected effects of changing seawater temperatures on the geographic-distribution of seaweed species. Expected Effects of Climatic Change on Marine Coastal Ecosystems 57, 69-76.

Burrows, M.T., Schoeman, D.S., Buckley, L.B., Moore, P., Poloczanska, E.S., Brander, K.M., Brown, C., Bruno, J.F., Duarte, C.M., Halpern, B.S., 2011. The pace of shifting climate in marine and terrestrial ecosystems. Science 334, 652-655.

Christie, H., Norderhaug, K.M., Fredriksen, S., 2009. Macrophytes as habitat for fauna. Marine Ecology - Progress Series 396, 221-233.

Cosson, J., 1999. Sur la disparition progressive de Laminaria digitata sur les cotes du Calvados (France). Cryptogamie Algologie 20, 35-42.

DAISIE European Invasive Alien Species Gateway, 2008. Asparagopsis armata. Available from: http://www.europe-aliens.org/speciesFactsheet.do?speciesId= 50124\# (accessed 25.05.12.)

Daly, B., Konar, B., 2010. Temporal trends of two spider crabs (Brachyura, Majoidea) in nearshore kelp habitats in Alaska, USA. Crustaceana 83, 659-669.

Dieck, I.T., 1992. North Pacific and North-Atlantic Digitate Laminaria species (Phaeophyta) - hybridization experiments and temperature responses. Phycologia $31,147-163$.

Diez, I., Muguerza, N., Santolaria, A., Ganzedo, U., Gorostiaga, J.M., 2012. Seaweed assemblage changes in the eastern Cantabrian Sea and their potential relationship to climate change. Estuarine Coastal and Shelf Science 99, 108-120.

Duggins, D.O., 1980. Kelp beds and sea otters - an experimental approach. Ecology 61, 447-453.

Fernandez, C., 2011. The retreat of large brown seaweeds on the north coast of Spain: the case of Saccorhiza polyschides. European Journal of Phycology 46, $352-360$.
Flores, A.A.V., Paula, J., 2001. Intertidal distribution and species composition of brachyuran crabs at two rocky shores in Central Portugal. Hydrobiologia 449, 171-177.

Freire, J., González-Gurriarán, E., 1998. New approaches to the behaviour ecology of decapod crustaceans using telemetry and electronic tags. Hydrobiologia 371/ 372, 123-132.

Garcia, P., Pesquera, L.M.G., Redondo, E.Z., 2011. Macroalgae in the intertidal zone of Cantabrian Sea: richness, cover of characteristic and opportunistic species. Aquatic Conservation-Marine and Freshwater Ecosystems 21, 7-16.

Gomez-Gesteira, M., Decastro, M., Alvaez, I., Gomez-Gesteira, J.L., 2008. Coastal sea surface temperature warming trend along the continental part of the Atlantic Arc (1985-2005). Journal of Geophysical Research - Oceans 113.

Goodsell, P.J., Connell, S.D., 2002. Can habitat loss be treated independently of habitat configuration? Implications for rare and common taxa in fragmented landscapes. Marine Ecology Progress Series 239, 37-44.

Gorostiaga, J.M., Santolaria, A., Secilla, A., Casares, C., Diez, I., 2004. Check-list of the Basque coast benthic algae (N Spain). Anales del Jardín Botánico de Madrid 61, $155-180$.

Gutiérrez morán, J.A., 1994. Descripción de las comunidades dominadas por macroalgas en la costa de Asturias, 48. Unidad de ecología, Departamento de Biología de Organismos y Sistemas, Universidad de Oviedo.

Hammer, D.Ø., Harper, R.P.D., 2001. PAST: palaeontological statistics software package for education and data analysis. Palaeontologia Electronica 4, 1-9.

Ingle, R.W., 1980. British Crabs. British Museum (Natural History)/Oxford University Press, London/Oxford

IPCC, 2001. Climate change 2001: the scientific basis. In: Houghton, J.T., Ding, Y., Griggs, D.J., Noguer, M., van der Linden, P.J., Dai, X., Maskell, K., Johnson, C.A. (Eds.), Contribution of Working Group I to the Third Assessment Report of the Intergovernmental Panel on Climate Change. Cambridge University Press, Cambridge, United Kingdom and New York, NY, USA, p. 881.

Irigoyen, A.J., Trobbiani, G., Sgarlatta, M.P., Raffo, M.P., 2011. Effects of the alien algae Undaria pinnatifida (Phaeophyceae, Laminariales) on the diversity and abundance of benthic macrofauna in Golfo Nuevo (Patagonia, Argentina) potential implications for local food webs. Biological Invasions 13, 15211532.

Izquierdo, J.L., Perez-Ruzafa, I.M., Gallardo, T., 2002. Effect of temperature and photon fluence rate on gametophytes and young sporophytes of Laminaria ochroleuca Pylaie. Helgoland Marine Research 55, 285-292.

Jensen, O.P., Branch, T.A., Hilborn, R., 2012. Marine fisheries as ecological experiments. Theoretical Ecology 5, 3-22.

Johns, P., Mann, K., 1987. An experimental investigation of juvenile lobster habitat preference and mortality among habitats of varying structural complexity. Journal of Experimental Marine Biology and Ecology 109, 275-285.

Juanes, J.A., Guinda, X., Puente, A., Revilla, J.A., 2008. Macroalgae, a suitable indicator of the ecological status of coastal rocky communities in the NE Atlantic. Ecological Indicators 8, 351-359.

Libralato, S., Pranovi, F., Raicevich, S., Da ponte, F., Giovanardi, O., Pastres, R. Torricelli, P., Mainardi, D., 2004. Ecological stages of the Venice Lagoon analysed using landing time series data. Journal of Marine Systems 51, 331-344.

Lima, F.P., Ribeiro, P.A., Queiroz, N., Hawkins, S.J., Santos, A.M., 2007. Do distributional shifts of northern and southern species of algae match the warming pattern? Global Change Biology 13, 2592-2604.

Lima, F.P., Wethey, D.S., 2012. Three decades of high-resolution coastal sea surface temperatures reveal more than warming. Nature Communications 3.

Lünning, K., 1990. Seaweeds: Their Environment, Biogeography and Ecophysiology. Wiley and Sons, New York.

McNeill, S.E., 1992. Criteros para el es Table cimiento de zonas protegidas en la costa asturiana. Universidad de Oviedo, p. 72. Unpublished Report.

Moy, F.E., Christie, H., 2012. Large-scale shift from sugar kelp (Saccharina latissima) to ephemeral algae along the south and west coast of Norway. Marine Biology Research 8, 309-321.

Muller, R., Laepple, T., Bartsch, I., Wiencke, C., 2009. Impact of oceanic warming on the distribution of seaweeds in polar and cold-temperate waters. Botanica Marina 52, 617-638.

Norman, C.P., Jones, M.B., 1992. Influence of depth, season and molt stage on the diet of the velvet swimming crab Necora-puber (Brachyura, Portunidae). Estuarine Coastal and Shelf Science 34, 71-83.

Okada, E.K., Agostinho, A.A., Gomes, L.C., 2005. Spatial and temporal gradients in artisanal fisheries of a large neotropical reservoir: the Itaipu Reservoir, Brazil. Canadian Journal of Fisheries and Aquatic Sciences 62, 714-724.

Pereira, T., Engelen, A.H., Pearson, G., Serrao, E., Destombe, C., Valero, M., 2011 Temperature effects on gametophyte development of $L$. ochroleuca and $S$. polyschides, kelps with contrasting life histories. Cahiers de Biologie Marine 52, 395-403

Qui, Y., Lin, Z., Wang, Y., 2010. Responses of fish production to fishing and climate variability in the northern South China Sea. Progress in Oceanography 85, 197-212.

Reed, D.C., Schroeter, S.C., Raimondi, P.T., 2004. Spore supply and habitat availability as sources of recruitment limitation in the giant kelp Macrocystis pyrifer (Phaeophyceae). Journal of Phycology 40, 275-284.

Reynolds, R.W., Smith, T.M., Liu, C., Chelton, D.B., Casey, K., Schlax, M.G., 2007. Daily high-resolution-blended analyses for sea surface temperature. Journal of Climate 20, 5473-5496.

Sekiguchi, H., Booth, J.D., Webber, W.R., 2007. The Biology and Fisheries of the Slipper Lobster. CRC Press, pp. 69-90. 
Schiel, D.R., Steinbeck, J.R., Foster, M.S., 2004. Ten years of induced ocean warming causes comprehensive changes in marine benthic communities. Ecology 85, 1833-1839.

Schils, T., Wilson, S.C., 2006. Temperature threshold as a biogeographic barrier in northern Indian Ocean macroalgae. Journal of Phycology 42, 749-756.

Simpson, S.D., Jennings, S., Johnson, M.P., Blanchard, J.L., Schön, P.J., Sims, D.W. Genner, M.J., 2011. Continental shelf-wide response of a fish assemblage to rapid warming of the sea. Current Biology 21 (18), 1565-1570.

Smale, D.A., Wernberg, T., 2009. Satellite-derived SST data as a proxy for water temperature in nearshore benthic ecology. Marine Ecology - Progress Series 387, 27-37.

Smale, D.A., Wernberg, T., 2013. Extreme climatic event drives range contraction of a habitat-forming species. Proceedings of the Royal Society B: Biological Sciences 280.

Steneck, R.S., Graham, M.H., Bourque, B.J., Corbett, D., Erlandson, J.M., Estes, J.A., Tegner, M.J., 2002. Kelp forest ecosystems: biodiversity, stability, resilience and future. Environmental Conservation 29, 436-459.

Tanaka, K., Taino, S., Haraguchi, H., Prendergast, G., Hiraoka, M., 2012. Warming off southwestern Japan linked to distributional shifts of subtidal canopy-forming seaweeds. Ecology and Evolution 2 (11), 2854-2865.

Tuya, F., Cacabelos, E., Duarte, P., Jacinto, D., Castro, J.J., Silva, T., Bertocci, I., Franco, J.N., Arenas, F., Coca, J., 2012. Patterns of landscape and assemblage structure along a latitudinal gradient in ocean climate. Marine Ecology Progress Series 466, 9-19.

Valencia, V., Franco, J., Borja, Á., Fontán, A., 2004. Chapter 7 Hydrography of the southeastern Bay of Biscay. In: Borja, Á., Collins, M. (Eds.), Elsevier Oceanography Series. Elsevier, pp. 159-194.
Valentine, J.P., Magierowski, R.H., Johnson, C.R., 2007. Mechanisms of invasion: establishment, spread and persistence of introduced seaweed populations. Botanica Marina 50, 351-360.

Vandenhoek, C., 1982. The distribution of benthic marine-algae in relation to the temperature regulation of their life histories. Biological Journal of the Linnean Society $18,81-144$

Walker, F., 1956. Periodicity of the Laminariaceae around Scotland. Nature, London $177,1246$.

Wernberg, T., Campbell, A., Coleman, M.A., Connell, S.D., Kendrick, G.A., Moore, P.J. Russell, B.D., Smale, D., Steinberg, P.D., 2009. Macroalgae and temperate rocky reefs. In: Poloczanska, E.S., Hobday, A.J., Richardson, A.J. (Eds.), A Marine Climate Change Impacts and Adaptation Report Card for Australia 2009. NCCARF Publication 05/09, ISBN 978-1-921609-03-9.

Wernberg, T., Russell, B.D., Moore, P.J., Ling, S.D., Smale, D.A., Campbell, A., Coleman, M.A., Steinberg, P.D., Kendrick, G.A., Connell, S.D., 2011a. Impacts of climate change in a global hotspot for temperate marine biodiversity and ocean warming. Journal of Experimental Marine Biology and Ecology 400, 7-16.

Wernberg, T., Russell, B.D., Thomsen, M.S., Gurgel, C.F.D., Bradshaw, C.J.A., Poloczanska, E.S., Connell, S.D., 2011b. Seaweed communities in retreat from ocean warming. Current Biology 21, 1828-1832.

Wernberg, T., Smale, D.A., Tuya, F., Thomsen, M.S., Langlois, T.J., deBettignies, T., Bennett, S., Rousseaux, C.S, 2012. An extreme climatic event alters marine ecosystemstructure in a global biodiversity hotspot. Nature Climate Change. http://dx.doi.org/10.1038/nclimate1627.

Wernberg, T., Thomsen, M.S., Tuya, F., Kendrick, G.A., Staehr, P.A., Toohey, B.D., 2010. Decreasing resilience of kelp beds along a latitudinal temperature gradient: potential implications for a warmer future. Ecology Letters 13, 685-694. 